Article

\title{
Assessing Douglas-Fir Seedling Establishment Using Two Modified Forestry Reclamation Approaches in the Pacific Northwest
}

\author{
Colton Miller ${ }^{1}$, Grace King ${ }^{2}$, Yurong Liu ${ }^{3}$, Robert Harrison ${ }^{1}$, Eric Turnblom ${ }^{1}$ and \\ Darlene Zabowski ${ }^{1, *}$
}

1 School of Environmental and Forest Sciences, University of Washington, Box 352100, Seattle, WA 98195-2100, USA; E-Mails: cwm4@u.washington.edu (C.M.); robh@u.washington.edu (R.H.); ect@u.washington.edu (E.T.)

2 Gonzaga University School of Law, 721 North Cincinnati Street, Spokane, WA 99202, USA; E-Mail: gking@lawschool.gonzaga.edu

3 Arid Lands Resource Sciences, Graduate Interdisciplinary Program, University of Arizona, 1604 East Lowell Street, Tucson, AZ 85719, USA; E-mail: joyliu@email.arizona.edu

* Author to whom correspondence should be addressed; E-Mail: zabow@u.washington.edu; Tel.: +1-206-685-9550.

Academic Editor: Eric J. Jokela

Received: 3 July 2015 / Accepted: 17 August 2015 / Published: 21 August 2015

\begin{abstract}
The Forestry Reclamation Approach uses uncompacted, mounded spoils to reforest mined-land and has been successful in hardwood forests in the Appalachian region. A surface coalmine reclamation site in the Pacific Northwest was used to compare the site's standard reclamation approach (Reference) with a modified version of the Forestry Reclamation Approach (FRA) along with a modified FRA treatment that also incorporated an amendment of bottom ash from the coal burning power plant on-site (FRA + Ash). Survival and growth were followed for three growing seasons in bareroot and container Douglas-fir seedlings. Soil characteristics and understory cover were also assessed. Considerable variation in microsite characteristics was observed in the study area. Container seedlings did not improve survival compared to bareroot seedlings. In the soil reclamation treatments, seedling survival was significantly higher in FRA + Ash treatments compared to FRA and Reference treatments at the end of the second growing season. Survival declined in each year of the study, but the order of treatment effectiveness did not change. Relativized growth increment was significantly higher in the FRA treatment compared to both the
\end{abstract}


Reference and FRA + Ash treatments during the third growing season. Understory cover was established after three years, but varied substantially across the study area.

Keywords: soil reclamation; seedling survival; ash amendment

\section{Introduction}

Environmental and post-mining reclamation standards help reduce the impacts of overburden removal on the utility of the land. Surface mining can cause land use problems such as landslides, erosion, flooding, loss of wildlife habitat, and pollution. The Surface Mining and Control Reclamation Act (SMCRA) of 1977 requires that mined land be restored "to a condition capable of supporting the uses which it was capable of supporting prior to any mining, or higher or better uses ([1], p.62)." One unintended consequence of the act was to depress reforestation efforts at surface mines because of perceived increases in cost and risk, fear of misinterpreting the reforestation performance standards and longer bond-release waiting periods [2-4]. Currently, most active mining areas in the western U.S. consist of dry grassland and low shrubs [4].

Although grasslands that are on a trajectory to follow a predictable pathway of succession to a forest fulfill SMCRA requirements, the post-mining forest capability of the stands will likely be less than that prior to mining [2]. Trees play an important role in soil building, and their use during reclamation contributes to long-term soil improvement [3]. Suitable tree species develop deep root systems, improve drainage and aeration, and contribute to soil organic matter through leaf and branch litter [3]. Practices that maintain or increase soil organic matter can reduce the likelihood of high bulk density and compaction [5]. Improving the establishment of forests on mined-lands will contribute to more land use options in the future.

The Appalachian Region Reforestation Initiative (ARRI) formed as a result of the reduced reforestation efforts at surface coalmines. The ARRI has advocated the Forestry Reclamation Approach (FRA), a method that has proven successful for planting tree species to reclaim surface coalmines in the Appalachian region of the eastern U.S. using hardwoods [6]. There are five steps to the technique: (1) create a suitable $1.2 \mathrm{~m}$ deep rooting medium for good tree growth comprised of topsoil, weathered sandstone, or the best available material; (2) loosely grade the topsoil or topsoil substitutes placed on the surface to create an uncompacted growth medium; (3) use native and noncompetitive ground covers that are compatible with growing trees; (4) plant two types of trees-early succession species for wildlife and soil stability, and commercially valuable crop trees; and (5) use proper tree planting techniques [6].

At a surface coalmine in Washington State, soil compaction, understory vegetation, and water stress may be limiting factors to seedling establishment [7]. With some modification, the FRA may improve tree seedling survival and growth compared to the standard reclamation practice. Differences in climate, vegetation, and resources in the region necessitate the use of site-specific tree species and understory covers. The general practice in the area is to use only Douglas-fir (Pseudotsuga menziesii (Mirbel) Franco var. menziesii) since it is both an early seral and late successional species and a valuable timber species in the region. Therefore, only one tree species was planted in this study. Because of the harsh 
conditions on some areas of the mine [7], this study assessed survival of container Douglas-fir seedlings in addition to bareroot seedlings, the current reclamation standard.

This study compared a modified version of the FRA, a similarly modified version that also incorporated an amendment of bottom from the coal burning power plant on-site (FRA + Ash), and the mine's standard reclamation practice (Reference). Survival and growth of bareroot and container Douglas-fir seedlings was followed for three growing seasons. Soil properties, understory vegetation, and precipitation were monitored to describe site properties. The main objective of the study was to investigate whether the soil reclamation treatments impacted the early survival and growth of outplanted Douglas-fir seedlings. We hypothesized that (1) seedlings would have higher survival and growth in the FRA and FRA + Ash treatments compared to the Reference treatment and (2) container seedlings would have higher survival compared to the bareroot seedlings.

\section{Experimental Section}

\subsection{Site Description}

The study site is located approximately $10 \mathrm{~km}$ northeast of the city of Centralia, Washington at an open pit sub-bituminous coalmine. There is also an active coal-burning power plant on-site. The mine had been one of the most productive in the state, producing an average of 4.3 million tons of coal annually [8] until mining stopped in 2006. Efforts to reforest the area have been going on since mining started in 1971.

The climate of the region has an average annual precipitation of $1195 \mathrm{~mm}$, about $30 \%$ of which falls during the growing season, March through August. Mean temperatures range from a low of $4.5{ }^{\circ} \mathrm{C}$ in December to a high of $19.2{ }^{\circ} \mathrm{C}$ in August [9]. Precipitation for each month from the start of mining in 1971 through the third growing season (2012) was measured at the mine. The precipitation for the first three growing seasons after planting $(2010,2011$, and 2012) as compared with the previous thirty-year average 1980-2009 is shown in Table 1. The growing season for conifers in the region is approximately March through August. The first growing season after planting had above average precipitation for much of the year, with some deficits during July, August, and November. The second and third growing seasons after planting had wet months early in the year but underwent prolonged drought during the latter half of the growing season.

Table 1. Monthly precipitation at the mine site for the first three growing seasons after planting $(2010,2011$, and 2012) and previous thirty-year average (1980-2009).

\begin{tabular}{|c|c|c|c|c|c|c|c|c|c|c|c|c|}
\hline \multicolumn{13}{|c|}{ Precipitation } \\
\hline \multirow{3}{*}{ Year } & \multicolumn{12}{|c|}{ Month } \\
\hline & January & February & March & April & May & June & July & August & September & October & November & December \\
\hline & \multicolumn{12}{|c|}{$\mathbf{m m}$} \\
\hline 1980-2009 & 180 & 120 & 130 & 100 & 70 & 50 & 20 & 30 & 50 & 110 & 210 & 180 \\
\hline 2010 & 160 & 120 & 140 & 120 & 140 & 100 & 10 & 10 & 120 & 140 & 120 & 180 \\
\hline
\end{tabular}


Table 1. Cont.

\begin{tabular}{|c|c|c|c|c|c|c|c|c|c|c|c|c|}
\hline \multicolumn{13}{|c|}{ Precipitation } \\
\hline \multirow{3}{*}{ Year } & \multicolumn{12}{|c|}{ Month } \\
\hline & January & February & March & April & May & June & July & August & September & October & November & December \\
\hline & \multicolumn{12}{|c|}{$\mathbf{m m}$} \\
\hline 2011 & 170 & 110 & 230 & 150 & 110 & 30 & 20 & 0 & 20 & 90 & 210 & 90 \\
\hline 2012 & 170 & 170 & 240 & 130 & 70 & 60 & 20 & 0 & 0 & 190 & 250 & 280 \\
\hline
\end{tabular}

Soils in the area are primarily the Centralia Series (Fine-loamy, mixed, superactive, mesic Xeric Palehumults) or the Buckpeak Series (Fine-loamy, mixed, superactive, mesic Xeric Palehumults), which are very deep, well drained Ultisols formed in weathered sandstone or siltstone [10,11]. They are characterized by deep A horizons, up to $40 \mathrm{~cm}$ thick, and by clay-rich argillic (Bt) horizons down to $150 \mathrm{~cm}$. The region supports extensive coniferous forests, with Douglas-fir being the most valuable and common timber species; grand fir (Abies grandis (Dougl. ex D. Don) Lindl.), western redcedar (Thuja plicata Donn ex D. Don), and western hemlock (Tsuga heterophylla (Raf.) Sarg.) are also prevalent [12]. Dominant Douglas-fir trees in productive stands near the study site can reach heights of $41 \mathrm{~m}$ over a 50 -year period [11].

\subsection{Site Preparation and Plot Layout}

The reclamation area used for this study was re-graded during the summer of 2006. After mining, the stockpiled spoils were mixed and replaced. They contained fragments of coal and fossilized shells throughout [13]. The area was ripped to depths of 60-75 cm, and a mix of nitrogen fertilizer and understory seeds was applied by helicopter. The following species have been used for groundcover during reclamation at the mine: alsike clover (Trifolium hybridum L.), bentgrass (Agrostis castellana L.), birdsfoot trefoil (Lotus corniculatus L.), annual ryegrass (Lolium perenne L.), orchardgrass (Dactylis glomerata L.), perennial ryegrass (Lolium perenne L.), red clover (Trifolium pratense L.), red fescue (Festuca rubra L.), white clover (Trifolium repens L.) [7].

In the fall of 2009, twelve 1-ha plots were located surrounding an approximately 16-ha hill with varying aspects and slopes. The experiment was laid out in a split plot model, with whole plot treatments in a completely randomized design. Each whole plot treatment area was 1 ha with a $20 \mathrm{~m}$ buffer surrounding two $40 \mathrm{~m}$ by $40 \mathrm{~m}$ split plots, with either a Reference, FRA, or FRA + Ash treatment applied to the whole plot. Bareroot and container Douglas-fir seedlings were planted in randomly assigned split plot units (Figure 1). For data collection, three $10 \mathrm{~m}$ by $10 \mathrm{~m}$ subplots were randomly located within each split-plot. These three measurement subplots were used to sample survival, height, soil properties, and understory vegetation. The quantities were averaged across each split-plot experimental unit before analysis. 


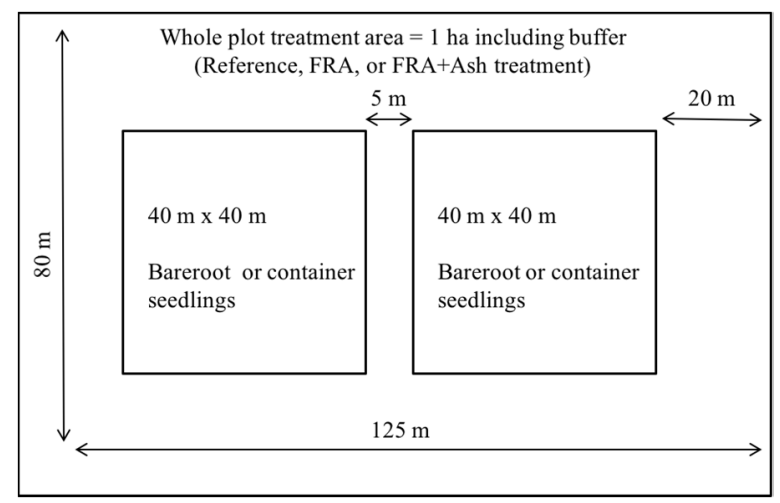

Figure 1. Example of an experimental unit where soil reclamation treatments (Reference is the standard mine reclamation technique, FRA is the modified Forestry Reclamation Approach, and FRA + Ash is the modified Forestry Reclamation Approach with an addition of bottom ash from the on-site coal burning power plant.) are applied to the whole plot treatment area and bareroot or container Douglas-fir seedlings to nested split plots. Three 10 $\mathrm{m}$ by $10 \mathrm{~m}$ subplots were randomly located within each split-plot for sampling.

All treatment plots were re-graded in 2009. In the FRA and FRA + Ash treatment areas, stockpiled spoils were placed in mounds on top of the re-graded land. Modifications in the FRA and FRA + Ash treatments implemented for use in the study area were: (1) only Douglas-fir was planted since it is considered both an early and late successional species and is also a commercially-valuable timber species in the region, (2) understory species suitable to Washington State were used, namely annual ryegrass and biannual sicklekeel lupine (Lupinus albicaulis Dougl.), and (3) since the mine uses larger dump trucks, if mounds were over $1.2 \mathrm{~m}$ they were slightly compressed by a bulldozer to the proper height.

The FRA + Ash treatment also incorporated bottom ash from the on-site power plant to evaluate the potential impacts of the soil amendment on seedling establishment as well as provide an option for disposing of the materials, an increasing concern in the industry [14]. The bottom ash was applied at a calculated average depth of $2.5 \mathrm{~cm}$ over the 1 ha plots and mixed into the replaced spoils using caterpillars before mound placement by bulldozers. It had a $\mathrm{pH}$ of 9.9 and contained $19,300 \mathrm{mg} \cdot \mathrm{kg}^{-1}$ aluminum, although other metal concentrations were relatively low [13].

In the spring of 2010, the Douglas-fir seedlings were hand-planted by professional tree planters. Half were $1+1$ bareroot Douglas-fir seedlings, planted at 1200 trees per ha ( $2.9 \mathrm{~m}$ spacing) and the other half were $p+0$ "plug-15" (in $15 \mathrm{~cm}^{3}$ soil) container Douglas-fir seedlings, planted at 1700 trees per ha (2.4 m spacing). Both seedling types came from local seed source. The $1+1$ seedlings were grown for one year in an outdoor nursery bed, then lifted, graded, and transplanted back into the nursery and grown for an additional year. The $\mathrm{p}+0$ "plug-15" seedlings were grown for one year in a small container in a greenhouse and then extracted. Differing densities were a result of seedling quantities received and were assumed not to influence seedling survival and growth over the first three years since crown closure had not occurred in either treatment. Since fixed plot areas were sampled in each split plot, the number of seedlings sampled differed between the stock types; there was an average of 12 bareroot seedlings planted per $100 \mathrm{~m}^{2}$ sampling subplot whereas container seedlings had an average of 17 seedlings planted per $100 \mathrm{~m}^{2}$ subplot. Seedling position relative to soil mounding was not considered during planting or sampling. 


\subsection{Seedling Survival and Growth}

Seedlings were surveyed in each measurement subplot at the end of the three growing seasons after planting (2010, 2011, and 2012). Seedlings were considered living if they had any green foliage on them. The total number of seedlings planted in each subplot was determined by the sum of live trees and dead trees found in the subplots at the end of the first growing season, as well as obvious missing seedlings based on planting row spacing. There was evidence of elk browsing on seedlings, and elk had pulled out some seedlings. Since the overall goal of the study was to assess the impact of using the modified FRA treatments on the site, and elk might have preferred certain treatments because of their accessibility or other soil characteristics, these data were retained in the analysis. All missing seedlings were recorded with the bareroot seedling type, with 30 missing in the Reference treatment and 20 in the FRA treatment. Elk mostly uprooted seedlings during the first growing season after planting.

The percentage of surviving trees in each plot was calculated as a mean of the ratio of live trees to total planted trees in the three subplots. Since the seedlings were spaced roughly $2.4-2.9 \mathrm{~m}$ apart, different initial starting density for the two seedling types should not affect the proportion of surviving seedlings for either type. Bareroot seedlings were one year older and generally bigger than container seedlings at the time of planting. The survival and growth analyses are based on the age of the seedlings since the time of outplanting (plantation age).

Seedling annual height increment was measured at the end of the third growing season (2012) in each of the three subplots per split plot and relativized by total seedling height. In some cases where few seedlings survived, measurements were taken on seedlings adjacent to the subplots to maintain a minimum sample size of six. Since different numbers of seedlings were measured for height in each subplot due to varying survival, a weighted average of the seedling growth (based on number of surviving seedlings) across the three subplots was calculated for each split plot unit.

\subsection{Soil Characteristics}

Soils were sampled in each plot in late spring and early summer of 2010. Three sampling locations in each split plot were randomly located adjacent to each of the measurement plots, inside the treatment area, and excavated to $50 \mathrm{~cm}$. Samples were collected from outside the measurement plots to avoid disturbing seedlings or impacting survival and growth measurements. Separate bulk density and mineral samples were collected from the following depths: 0-5 cm, 5-15 cm, and 15-50 cm. Samples were stored at $3{ }^{\circ} \mathrm{C}$ until chemical analysis.

Bulk density samples were taken from each depth using a $137.4 \mathrm{~cm}^{3}$ two-ring corer (in some cases where difficult, a $68.7 \mathrm{~cm}^{3}$ core), and oven-dried at $105{ }^{\circ} \mathrm{C}$ for $72 \mathrm{~h}$. Dry mass of the soil was used to calculate bulk density. Soil chemical samples were prepared for analysis by air-drying for one week and sieving to $2 \mathrm{~mm}$. Soil $\mathrm{pH}$ was measured using a Denver Instrument Model $220 \mathrm{pH}$ meter in a 2-to-1 ratio of de-ionized water to air-dried, sieved soil, kept at approximately $21{ }^{\circ} \mathrm{C}$ and equilibrated for $30 \mathrm{~min}$ after stirring. Total carbon $(\mathrm{C})$ and nitrogen $(\mathrm{N})$ were analyzed using dry combustion with a Perkin Elmer 2400 CHN Analyzer (Perkin-Elmer, Shelton, CT, USA). Other elements were analyzed using a Thermo Jarrell Ash ICAP model 61E spectrophotometer (Thermo Jarrell Ash, Ithaca, NY, USA) after acid digestion using the Environmental Protection Agency (EPA) Method 3050 [15]. 


\subsection{Understory Cover and Species}

Three replicate $20 \mathrm{~m}$ transects were used to measure understory cover in each whole plot. This was done after the growing season had ended, in September through October of the first and second growing seasons (2010 and 2011). Percent cover was estimated using ocular assessment of cover on each $20 \mathrm{~m}$ transect using $1 \mathrm{~m}$ intervals. Understory species were assessed within a $1 \mathrm{~m}$ by $1 \mathrm{~m}$ quadrat at one random location within each subplot and averaged by whole-plot treatment. Total species cover was not allowed to exceed $100 \%$, as only the top layer of cover was measured.

\subsection{Soil Moisture and Temperature}

Soil temperature at $10 \mathrm{~cm}$ and soil moisture at 10 and $50 \mathrm{~cm}$ were recorded at noon and midnight at one location within each whole plot using Decagon data loggers connected to Decagon EC-5 moisture probes and a Decagon ECT temperature probe (Decagon Devices, Pullman, WA, USA). The sampling locations were randomly located without regard to the placement relative to mounds on the site. Data were collected for two consecutive growing seasons after planting (2010 and 2011). Trend lines were added to the graphs by computing moving averages on the individual data points.

\subsection{Statistical Analysis}

All statistical analyses were performed using R Statistical Software version 2.14.0 (R Development Core Team, Vienna, Austria). A Type I error value of 0.10 was used for all tests. Tukey's honestly significant difference (HSD) tests were used to determine where significant differences occurred in analysis of varriance (ANOVA) models and 90\% confidence intervals were produced for distinct means. The soil reclamation treatment (Reference, FRA, FRA + Ash) was considered the whole plot factor and seedling type (bareroot, container) the split-plot factor to test differences in survival and growth after the third growing season. Sampling year $(2010,2011,2012)$ was added as a split-split plot factor for analysis of trends over the three-year period. For the height increment analysis, plot 10 was omitted from the analysis because there were no surviving seedlings to measure. An unbalanced ANOVA with Type II sums of squares was used to test equality of means and Tukey-Kramer for multiple comparisons.

\section{Results and Discussion}

\subsection{Seedling Survival and Density}

The FRA + Ash treatment had the highest survival at the end of each growing season, followed by the FRA, with the Reference treatments having the lowest survival (Figure 2). The effect of the soil reclamation treatments on seedling survival was nearly significant at the end of the first growing season $(p=0.106)$. At the end of the second growing season, seedling survival differed significantly due to soil reclamation treatment $(p=0.017)$, with the FRA + Ash treatment having significantly higher survival than both the Reference and FRA treatment. The $F$-test for the treatment effect was still significant at the end of the third growing season $(p=0.072)$ although multiple comparisons did not reveal differences between treatments. The order of treatment effectiveness did not change throughout the study, and 
seedling survival declined in each subsequent year. There was no significant difference in survival between bareroot and container seedlings in any individual year.

Analyzing the data for trends over the three growing seasons, thus accounting for the decreasing survival over that period, revealed a significant interaction between seedling type and year $(p=0.001)$. Bareroot and container seedlings could not be distinguished from one another after the first or second growing season (Figure 3). After the third growing season, bareroot seedlings had higher survival than container seedlings. The results do not support the hypothesis that planting container seedlings would increase the survival at the mine. Additionally, although elk seemed to prefer bareroot seedlings, the bareroot seedlings had higher survival than the container seedlings after three growing seasons.
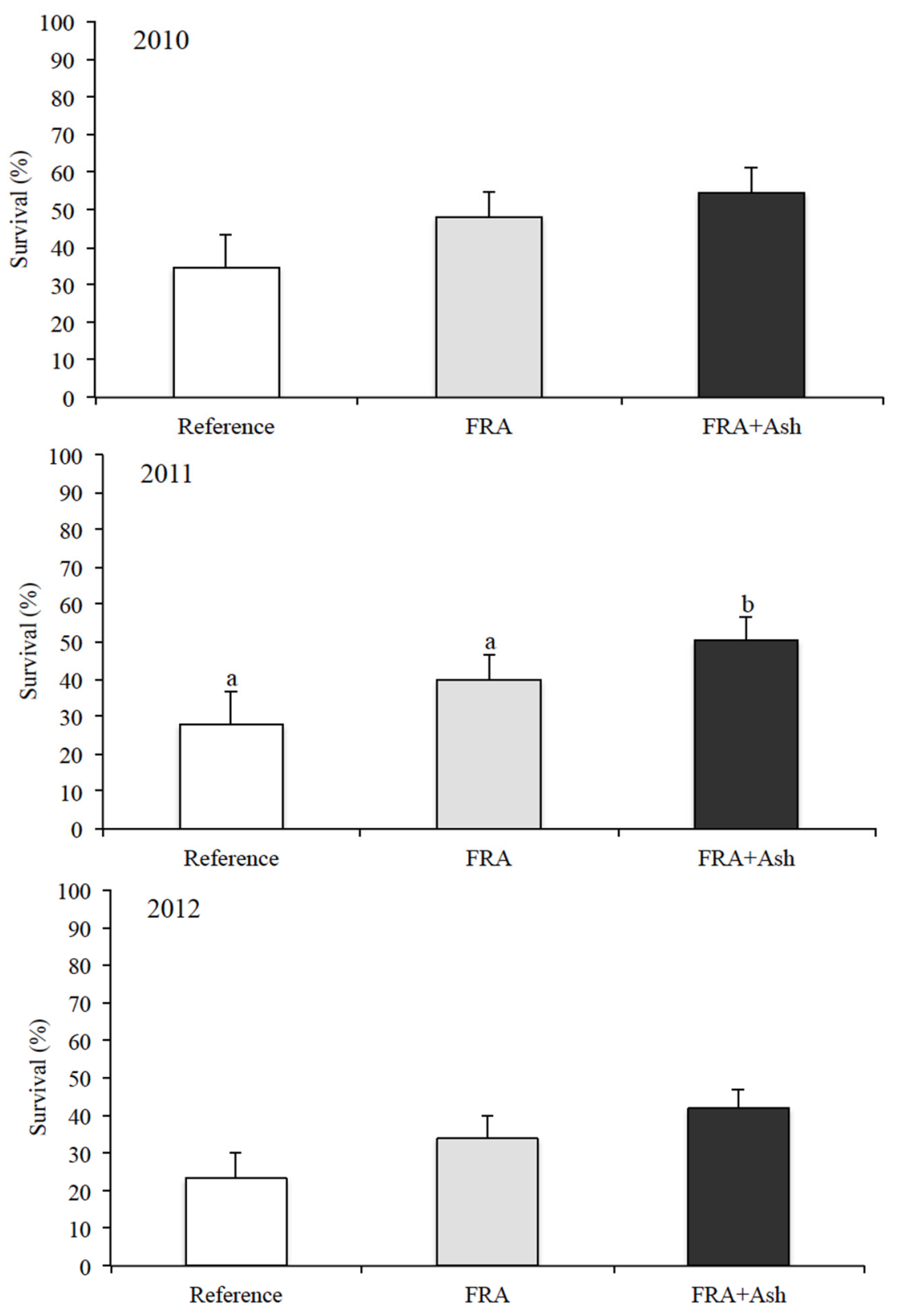

Figure 2. Mean survival with standard error after the first (2010), second (2011) and third (2012) growing season by reclamation treatment. Reference is the standard mine reclamation technique, FRA is the modified Forestry Reclamation Approach, and FRA + Ash is the modified Forestry Reclamation Approach with an addition of bottom ash from the on-site 
coal burning power plant. Lowercase letters indicate significant differences in survival between soil reclamation treatments.

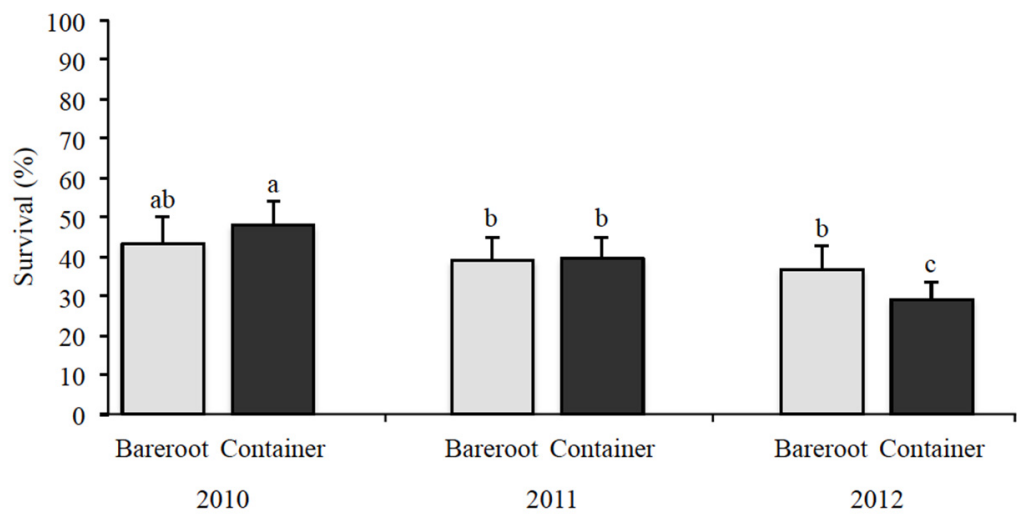

Figure 3. Mean survival with standard error after the first (2010), second (2011) and third (2012) growing season by seedling type. Lowercase letters indicate significant differences in survival between seedling types.

To determine reforestation success relative to legal standards, $90 \%$ confidence intervals were constructed for the mean survival in each whole plot treatment area. Based on these results, the stem density of the treatment areas was estimated using the average density of the bareroot and container seedlings combined (1450 trees per ha). The stem density of the treatments (Table 2) provides a straightforward comparison with reclamation success relative to Washington State forest practices, which dictate that a harvested area is reforested when it contains an average of at least 470 trees per ha of "vigorous, undamaged" commercial species seedlings that have survived on site for at least one growing season (WAC 222-34-010). All treatments meet the requirement of 470 trees per ha after the first growing season, with the FRA and FRA + Ash treatments exceeding standards and the Reference treatment marginally acceptable.

Table 2. Stem density of treatment plots after the first (2010), second (2011) and third growing season (2012) based on 90\% confidence intervals of mean survival and average initial planting density of bareroot and container Douglas-fir seedlings in the whole treatment area (1450 trees per ha). Reference is the standard mine reclamation technique, FRA is the modified Forestry Reclamation Approach, and FRA + Ash is the modified Forestry Reclamation Approach with an addition of bottom ash from the on-site coal burning power plant.

\begin{tabular}{cccc}
\hline \multirow{4}{*}{ Stem density } \\
\hline \multirow{3}{*}{ Year } & \multicolumn{3}{c}{ Treatment } \\
\cline { 2 - 4 } & Reference & FRA & FRA + Ash \\
\cline { 2 - 4 } Initial & 1450 & 1450 & 1450 \\
2010 & $450-551$ & $653-740$ & $740-841$ \\
2011 & $363-450$ & $537-624$ & $682-783$ \\
2012 & $290-377$ & $450-537$ & $566-653$ \\
\hline
\end{tabular}




\subsection{Seedling Growth}

During the third growing season, the height increment ranged from 8 to $29 \mathrm{~cm}$ for the bareroot seedlings from $11 \mathrm{~cm}$ to $18 \mathrm{~cm}$ for the container seedlings. The two seedling types did not differ significantly in their relative growth. Three years after planting, bareroot seedlings averaged $74 \mathrm{~cm}$ in height, whereas container seedlings averaged $68 \mathrm{~cm}$ in height. The mean height increment in that year was $17 \mathrm{~cm}$ for bareroot seedlings and $15 \mathrm{~cm}$ for container seedlings. Relativized growth was significantly different between soil reclamation treatments $(p=0.005)$ during the third growing season, with the FRA treatment having significantly higher relative growth than both the Reference and the FRA + Ash treatments (Figure 4).

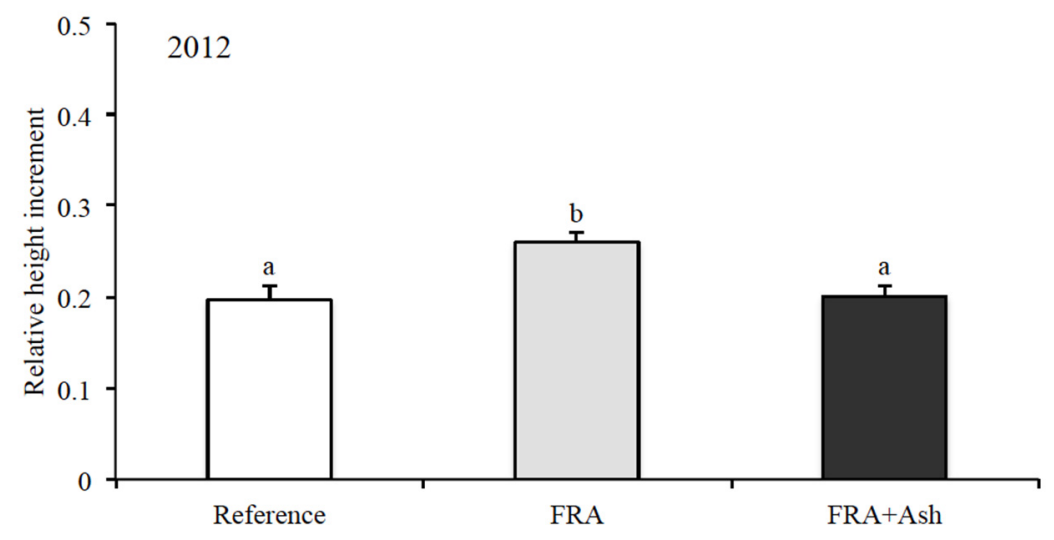

Figure 4. Relativized height increment with standard error for the third growing season (2012). Reference is the standard mine reclamation technique, FRA is the modified Forestry Reclamation Approach, and FRA + Ash is the modified Forestry Reclamation Approach with an addition of bottom ash from the on-site coal burning power plant. Lowercase letters indicate significant differences in relative height increment between soil reclamation treatments.

After outplanting, seedlings can experience drought stress and reduced growth until they have established in the new environment [16]. An adequate root system, nutrients, and water supply are essential to seedling survival and growth. Seedlings need to reestablish root-to-soil contact after transplanting, resume water and nutrient uptake, and recover from handling damage [16]. Growth can be reduced by transplant shock, which is probably due to moisture deficit [17]. Additionally, nursery carryover may impact growth rates during initial seedling establishment. In this study, seedling height increments were impacted by elk browse and tip dieback. Future research may consider as using stem diameter in addition to height increment to quantify seedling growth.

\subsection{Soil Characteristics}

The average bulk density ranged from 0.00131 to $0.00138 \mathrm{~kg} \cdot \mathrm{cm}^{-3}$ in the treatments (Table 3). Compaction is often a concern during site preparation and may negatively impact survival and growth rates. Although it is clearly established that heavy equipment compacts mineral soil, the consequences to tree growth and stand yields are less predictable [18]. Soil compaction can increase runoff and erosion and reduce root and shoot growth in plants. Low soil porosity inhibits the movement of air and water 
through soil [5]. In clayey soils, bulk densities over $0.00147 \mathrm{~kg} \cdot \mathrm{cm}^{-3}$ can restrict the root growth of plants, and the ideal bulk density for plant growth is under $0.00110 \mathrm{~kg} \cdot \mathrm{cm}^{-3}$ [5]. Since the levels of current compaction are adequate for plant establishment, other factors may be of higher importance to evaluating the survival of trees at the site. Soil nitrogen and other micronutrients may be a concern in soil productivity, as chlorotic foliage was observed in some seedlings. Average soil nutrient concentrations were generally low but not unusual for forest soils within all treatments.

Table 3. Mean soil bulk density, $\mathrm{pH}$ and nutrient concentrations by treatment of the reclaimed soil averaged according to sampling depths to $50 \mathrm{~cm}$. Reference is the standard mine reclamation technique, FRA is the modified Forestry Reclamation Approach, and FRA + Ash is the modified Forestry Reclamation Approach with an addition of bottom ash from the on-site coal burning power plant.

\begin{tabular}{|c|c|c|c|c|c|c|c|c|c|}
\hline \multicolumn{10}{|c|}{ Soil properties } \\
\hline \multirow{2}{*}{ Treatment } & $\mathbf{D}_{\mathbf{b}}$ & pH & $\mathrm{C}$ & $\mathbf{N}$ & $\mathbf{P}$ & $\mathbf{K}$ & $\mathbf{S}$ & $\mathbf{C a}$ & Mg \\
\hline & $\mathrm{kg} \cdot \mathrm{cm}^{-3}$ & & \multicolumn{2}{|c|}{$\mathrm{mg} \cdot \mathrm{g}^{-1}$} & \multicolumn{5}{|c|}{$\mu \mathrm{g} \cdot \mathrm{g}^{-1}$} \\
\hline Reference & 0.00131 & 6.4 & 18.2 & 0.6 & 700 & 2400 & 7900 & 11,600 & 5900 \\
\hline FRA & 0.00131 & 6.3 & 29.5 & 0.7 & 700 & 1600 & 5700 & 6700 & 5800 \\
\hline FRA + Ash & 0.00138 & 6.0 & 25.4 & 0.9 & 500 & 1500 & 4500 & 9500 & 5100 \\
\hline
\end{tabular}

The individual soil $\mathrm{pH}$ measurements were highly variable. When averaged across treatments, values were slightly acidic and ranged from 6.0 to 6.4. Douglas-fir has optimal growth in mineral soils that are moderately acidic, ranging in $\mathrm{pH}$ from about 5 to 6.5 [19]. The high variability of soil $\mathrm{pH}$ measurements was likely due to the high rainfall in the region, calcium carbonate fossils in the soil, strongly acidic microsites, and the mixing of original soil horizons during spoil replacement. There are a number of microsites in the area with poor drainage that hold water for much of the year, which may have contributed to variation in $\mathrm{pH}$ and other nutrients. Mounding the replaced spoils in the FRA and FRA + Ash treatments likely increased the occurrence of these sites. Although the average soil pH of each treatment was acceptable for Douglas-fir growth, the range in $\mathrm{pH}$ from under 3.0 to over 8.0 for individual measurements indicates potential problems from acidity in some microsites [13]. Some sites have $\mathrm{pH}$ values not optimal for seedling establishment, but these occurred in all treatment areas.

\subsection{Understory Cover and Species}

The Reference treatment had established dense understory cover by the end of the first growing season (Table 4). The FRA and FRA + Ash plots had much lower understory cover after the first growing season, though by the end of the second growing season understory had become well established on all treatments. In general, the understory vegetation was higher than seedling height after the first growing season. Tree seedlings began to overtake tall grasses and shrubs after three years. Understory cover was highly variable within and among treatments ranging from full coverage to virtually none. 
Table 4. Mean percent understory cover and standard error by treatment after the first (2010) and second (2011) growing season, with standard error of the mean in parentheses. Reference is the standard mine reclamation technique, FRA is the modified Forestry Reclamation Approach, and FRA + Ash is the modified Forestry Reclamation Approach with an addition of bottom ash from the on-site coal burning power plant (SE: standard eror).

\begin{tabular}{|c|c|c|}
\hline \multicolumn{3}{|c|}{ Understory Cover } \\
\hline \multirow{3}{*}{ Treatment } & \multicolumn{2}{|c|}{ Year } \\
\hline & 2010 & 2011 \\
\hline & \multicolumn{2}{|c|}{$\%(\mathrm{SE})$} \\
\hline Reference & $94(3)$ & $94(4)$ \\
\hline FRA & 49 (13) & $74(12)$ \\
\hline FRA + Ash & $58(14)$ & $86(10)$ \\
\hline
\end{tabular}

Birdsfoot trefoil (Lotus corniculatus) had established in all treatments by the end of the second growing season (Table 5). Birdsfoot trefoil is a perennial herbaceous plant that is considered invasive in Washington State [20]. It encroached onto the FRA and FRA + Ash plots during the second growing season, which may have increased competition for site resources, including water, nutrients, and light. Low soil nitrogen could explain the presence of birdsfoot trefoil which is a nitrogen-fixing species and would be consistent with its ability to adapt to disturbed sites. In some areas the grass cover is dense, especially in the dryer microsites such as south-facing aspects and upper portions of the hill. Other seeded and unseeded plants generally covered only a small percentage of the treatment area.

A well-established understory cover aids in organic matter accumulation and can improve soil structure in the surface horizon, however it also plays a role in competing with seedlings during establishment. Less competitive understory species such as native species might provide similar erosion control benefits in the first year and not compete with seedlings as strongly for moisture [21]. Early establishment of understory cover in Douglas-fir plantations can decrease seedling growth because of competition for soil moisture during the dry summer months [22]. Water is a principle-limiting factor of Douglas-fir seedling growth [23]. Seedling desiccation was observed as a principle factor in seedling mortality across the all soil treatments. The heavy understory cover and high seedling mortality in the Reference plots during the first growing season suggests that it may be beneficial to time the planting of seedlings and the establishment of groundcover to minimize simultaneous competition for the site's resources. 
Table 5. Mean abundance of some understory species by treatment and year, with standard error of the mean in parentheses. Reference is the standard mine reclamation technique, FRA is the modified Forestry Reclamation Approach, and FRA + Ash is the modified Forestry Reclamation Approach with an addition of bottom ash from the on-site coal burning power plant. In some cases, species were not found in the treatment area (NF: not found; SE: standard error).

\begin{tabular}{|c|c|c|c|c|c|c|}
\hline \multicolumn{7}{|c|}{ Understory Species } \\
\hline \multirow{4}{*}{ Species } & \multicolumn{6}{|c|}{ Treatment by Year } \\
\hline & \multicolumn{2}{|c|}{ Reference } & \multicolumn{2}{|c|}{ FRA } & \multicolumn{2}{|c|}{$\mathbf{F R A}+\mathbf{A s h}$} \\
\hline & 2010 & 2011 & 2010 & 2011 & 2010 & 2011 \\
\hline & \multicolumn{6}{|c|}{$\%(\mathrm{SE})$} \\
\hline Lupinus albicaulis Dougl. & $3(2)$ & $2(1)$ & $5(4)$ & $4(3)$ & $2(1)$ & $1(0)$ \\
\hline Lotus corniculatus L. & $54(12)$ & $55(9)$ & $20(4)$ & $42(6)$ & $35(7)$ & $60(9)$ \\
\hline Lolium multiflorum perenne L. & $9(3)$ & $5(3)$ & $10(3)$ & $3(2)$ & $7(3)$ & $3(1)$ \\
\hline Trifolium pretense L. & NF & $2(0)$ & NF & $1(1)$ & NF & $1(1)$ \\
\hline Other Graminoids & $6(2)$ & $17(4)$ & $4(0)$ & $8(1)$ & $9(5)$ & $6(4)$ \\
\hline Unseeded plants & $11(3)$ & $9(4)$ & $10(1)$ & $10(6)$ & $6(1)$ & $6(2)$ \\
\hline
\end{tabular}

\subsection{Soil Moisture and Temperature}

The soils showed increasing temperature and decreasing moisture in all treatments over the growing season (Figure 5). Soil temperatures peaked during July and began to cool down again in September. Temperatures were similar in all treatments during the first growing season. In the second growing season, the Reference treatment had the highest temperatures, followed by FRA + Ash and then FRA. Soil moisture decreased considerably between May and June and did not recover until September in the first growing season, and appeared to begin recovery at about the same time at the end of the second growing season. The soil moisture at $10 \mathrm{~cm}$ showed a dry-down in all treatments, especially during the first growing season, and soils decreased in volumetric water content from about $0.4 \mathrm{~m}^{3} \cdot \mathrm{m}^{-3}$ to about $0.2 \mathrm{~m}^{3} \cdot \mathrm{m}^{-3}$. In the first growing season, the FRA + Ash treatment maintained the highest moisture content, followed by the Reference treatment then the FRA treatment. During the second growing season, moisture content at $10 \mathrm{~cm}$ was generally highest in the Reference treatment, followed by the FRA treatment, and lowest in the FRA + Ash treatment. At $50 \mathrm{~cm}$, soil moisture followed a similar pattern of reduction and recovery during the growing season. In the first growing season, the FRA + Ash treatment dried down to about $0.3 \mathrm{~m}^{3} \cdot \mathrm{m}^{-3}$, while the Reference and FRA treatments dropped to about $0.2 \mathrm{~m}^{3} \cdot \mathrm{m}^{-3}$. During the second growing season, the Reference and FRA + Ash treatments decreased from around $0.4 \mathrm{~m}^{3} \cdot \mathrm{m}^{-3}$ at the start of the growing season to nearly $0.2 \mathrm{~m}^{3} \cdot \mathrm{m}^{-3}$ by the end of the growing season. The FRA treatment dropped abruptly to $0.2 \mathrm{~m}^{3} \cdot \mathrm{m}^{-3}$ in July and held steady through the rest of the growing season. Hot/dry summers and cool/wet winters drive the overall trends in temperature and moisture dry-down and recovery. 

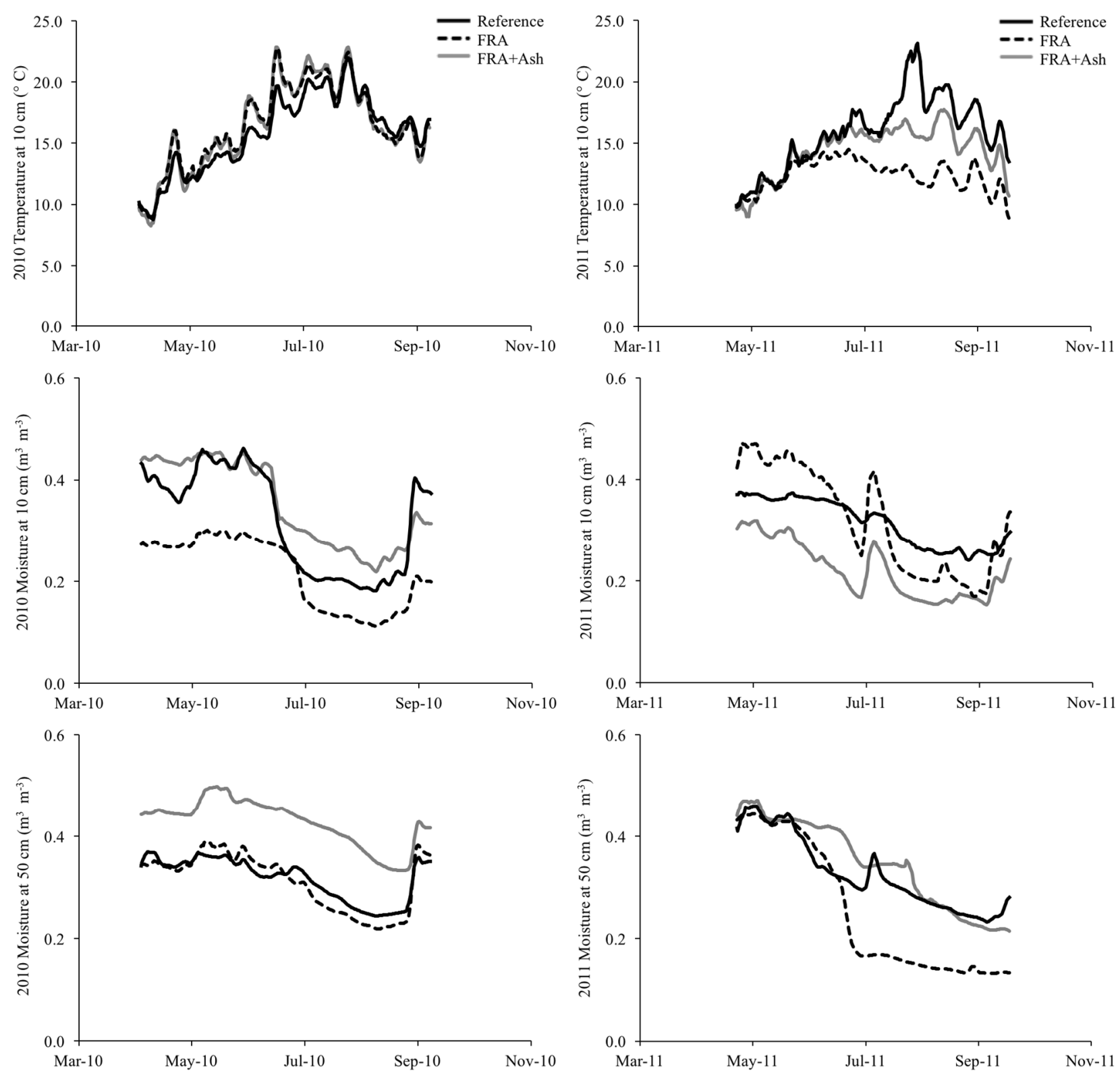

Figure 5. Soil temperature at $10 \mathrm{~cm}$, and soil moisture at $10 \mathrm{~cm}$ and $50 \mathrm{~cm}$ for the first $(2010)$ and second (2011) growing seasons. Reference (solid black line) is the standard mine reclamation technique, FRA (dashed black line) is the modified Forestry Reclamation Approach, and FRA + Ash (solid grey line) is the modified Forestry Reclamation Approach with an addition of bottom ash from the on-site coal burning power plant.

Moisture stress in the first year from transplanting the seedlings can inhibit their ability to take advantage of soil water [24]. That pressure can carry over to the second and third years (since buds are set in fall), which in this study provided less favorable water conditions during the growing season. The original soils that constituted the overburden in this study were high in clay content, so the seedlings may have been at a disadvantage to access what water supply did exist over the summer months. The plots dried considerably towards the end of each growing season, and although there was still moisture retained at depth, it may have been bound so tightly to the clay it was not available for plant use. The mounding of the FRA and FRA + Ash treatments and general topographic variation of the study 
area created individual microsites that ranged in soil moisture conditions that were potentially harmful to potentially beneficial in their impact on seedling establishment. Soil moisture results may be associated with the placement of sensors in relation to microsite conditions, such as position on mound, aspect, and slope. Quantifying the effect of seedling position relative to the mounds could help clarify the early impacts of local soil properties on seedling establishment.

\section{Conclusions}

Seedling survival was highest in the FRA + Ash treatments, followed by the FRA, with lowest survival in Reference treatments. Seedling survival declined in each treatment over the course of the study. Container seedlings did not show improved survival and growth compared to bareroot seedlings, and density levels were adequate in all three treatments after the first growing season according to local reforestation standards. Heavy understory competition and below average precipitation during the second and third growing seasons provided difficult conditions for seedling survival. These factors likely reduced access to water and nutrients on the site, which in turn led to seedling desiccation and chlorotic foliage. The timing of seedling outplanting and ground cover establishment may be a driver of early reforestation success. Microsite conditions, such as mound position, topography, and understory cover, varied substantially across the study area.

\section{Acknowledgments}

The authors wish to thank the Office of Surface Mining Reclamation and Enforcement for financial support and the TransAlta Corporation for making their reclamation area available for the project. We also thank Tim LeDuc for his support and assistance with the fieldwork.

\section{Author Contributions}

Colton Miller, Grace King, Yu Rong Liu, Robert Harrison, Eric Turnblom, and Darlene Zabowski designed the study and conducted the field trial. Colton Miller, Grace King, Yu Rong Liu, and Darlene Zabowksi were responsible for the sample collection and laboratory analysis. Colton Miller, Robert Harrison, Eric Turnblom, and Darlene Zabowski were responsible for the statistical analyses. Colton Miller, Robert Harrison, Eric Turnblom, and Darlene Zabowski wrote the paper.

\section{Conflicts of Interest}

The TransAlta Corporation helped locate study area, helped install study plots, and planted trees. The funding sponsors had no role in the collection, analyses, or interpretation of data, or in the writing of the manuscript. The authors declare no conflicts of interest.

\section{References}

1. Surface Mining and Coal Reclamation Act (SMCRA) 1977; USC §1202; 3 August 1977. Available online: http://www.osmre.gov/lrg/docs/SMCRA.pdf (accessed on 1 June 2013). 
2. Angel, P.N.; Burger, J.A.; Davis, V.M.; Barton, C.D.; Bower, M.; Eggerud, S.D.; Rothman, P. The Forestry Reclamation Approach and the measure of its success in Appalachia. In Proceedings of the National Meeting of the American Society of Mining and Reclamation, Barnhisel, R.I., Ed.; American Society of Mining and Reclamation: Lexington, KY, USA, 2009; pp. 18-36.

3. Ashby, W.C. Surface mine tree planting in the Midwest pre- and post- Public Law 95-87. In Proceedings of the American Society for Surface Mining and Reclamation, Durango, CO, USA, 14-17 May 1991; Oaks, W., Bowden, J., Eds.; American Society For Surface Mining and Reclamation: Durango, CO, USA, 1991; Volume 2, pp. 617-623.

4. Boyce, S. Office of surface mining (OSM) revegetation team survey results. In Proceedings of the Enhancement of Reforestation at Surface Coal Mines: Technical Interactive Forum, Fort Mitchell, KY, USA, 23-24 March 1999; Vories, K.C., Throgmorton, D., Eds.; U.S. Department of Interior, Office of Surface Mining, Coal Research Center at SIU: Carbondale, IL, USA, pp. 31-35.

5. U.S. Department of Agriculture. Soil Quality Indicators NRCS, 2008. Available online: http://soils.usda.gov/sqi/assessment/files/bulk_density_sq_physical_indicator_sheet.pdf (accessed on 1 June 2013)

6. Burger, J.; Graves, D.; Angel, P.; Davis, V.; Zipper, C. The Appalachian Regional Reforestation Initiative. In Forest Reclamation Advisory Number 2; U.S. Office of Surface Mining: Washington, DC, USA, 2005; p. 4.

7. King, S.T. Factors Affecting the Growth and Survival of Douglas-Fir on a Reclaimed Coal Mine Near Centralia, Washington. Master's Thesis, University of Washington, Seattle, WA, USA, 2010.

8. Schasse, H.W. Washington's Coal Industry, 1997. Wash. Geol. 1998, 26, 11-12.

9. Western Regional Climate Center. Available online: http://www.wrcc.dri.edu/climatedata /climsum/ (accessed on 1 June 2013).

10. Evans, R.L.; Fibich, W.R. Soil Survey of Lewis County Area, Washington; United States Department of Agriculture, Soil Conservation Service: Washington, DC, USA, 1987; p. 466.

11. Pringle, R.F. Soil Survey of Thurston County, Washington; United States Department of Agriculture, Soil Conservation Service: Washington, DC, USA, 1990; p. 283.

12. Snavely, P.D.; Brown, R.D.; Roberts, A.E. Geology and Coal Resources of the Centralia-Chehalis District, Washington, with a Section on Microscopical Character of the Centralia-Chehalis Coal; Geological Survey Bulletin 1053; U.S.G.P.O.: Washington, DC, USA, 1958; p. 159.

13. King, G.K. Assessing a Modified Forestry Reclamation Approach for Douglas-Fir in Southwestern Washington State. Master's Thesis, University of Washington, Seattle, WA, USA, 2011.

14. Krzaklewski, W.; Pietrzykowski, M.; Wos, B. Survival and growth of alders (Alnus glutinosa (L.) Gaertn. And Alnus incana (L.) Moench) on fly as technosols at different substrate improvement. Ecol. Eng. 2012, 49, 35-40.

15. U.S. Environmental Protection Agency. Method 3050B Revision 2. 1996. Available online: http://www.epa.gov/waste/hazard/testmethods/sw846/pdfs/3050b.pdf (accessed on 1 June 2013).

16. Haase, L.D.; Rose, R. Soil moisture stress induces transplant shock in stored and unstored $2+0$ Douglas-fir seedlings of varying root volumes. For. Sci. 1993, 39, 275-294.

17. Morgan, J.M. Osmoregulation and water stress in higher plants. Ann. Rev. Plant Physiol. 1984, 35, 299-319. 
18. Miller, R.E.; Scott, W.; Hazard, J.W. Soil compaction and conifer growth after tractor yarding at three coastal Washington locations. Can. J. For. Res. 1996, 26, 225-236.

19. Brady, N.; Weil, R. Soil Acidity, Alkalinity, and Salinity. In Elements of the Nature and Properties of Soils, 3rd ed.; Prentice Hall Pub: Upper Saddle River, NJ, USA, 2010; pp. 266-315.

20. Bush, T. Birdsfoot trefoil plant fact sheet. In National Resources Conservation Service; U.S. Department of Agriculture: Washington, DC, USA, 2002; p. 2.

21. Torbert, J.L.; Burger, J.A. Forest land reclamation. In Reclamation of Drastically Disturbed Lands; American Society of Agronomy: Madison, WI, USA, 2000; Volume 41, pp. 371-398.

22. Dinger, J.E.; Rose, R. Integration of soil moisture, xylem water potential, and fall-spring herbicide treatments to achieve the maximum growth response in newly planted Douglas-fir seedlings. Can. J. For. Res. 2009, 39, 1401-1414.

23. Khan, R.S.; Rose, R.; Haase, D.L.; Sabin, T.E. Soil water stress: Its effects on phenology, physiology, and morphology of containerized Douglas-fir seedlings. New For. 1996, 12, 19-39.

24. Newton, M.; Preest, D.S. Growth and water relations of Douglas-fir seedlings under different weed control regimes. Weed Sci. 1988, 36, 653-662.

(C) 2015 by the authors; licensee MDPI, Basel, Switzerland. This article is an open access article distributed under the terms and conditions of the Creative Commons Attribution license (http://creativecommons.org/licenses/by/4.0/). 